\title{
Turbin Screw Untuk Pembangkit Listrik Skala Mikrohidro Ramah Lingkungan
}

\author{
Encu Saefudin, Tarsisius Kristyadi, Muhammad Rifki, Syaiful Arifin \\ Jurusan Teknik Mesin, Institut Teknologi Nasional (Itenas) Bandung \\ Email: encusaefudin9@gmail.com
}

\begin{abstract}
Type screw water turbine is a type of water turbine which has the potential for small scale power plants, where water turbine screw type is suitable for rivers in parts of Indonesia because the operation of the turbine require only a low head turbine. With the potential of irrigation water streams at the rate of $0.3302 \mathrm{m3} / \mathrm{s}$ in Banjaran village allows the installation of the turbines type screw. In the process of designing a water turbine type screw to be optimized turbine screw to determine the value of the ratio $d / D$, and then calculating mechanically to determine the dimensions of the turbine blades, the turbine shaft, the transmission system (gears, pulleys and belt) as well as the power that can be produced by the turbines, by using a head of 1.05 meters. The results of this research are the technical specifications of the turbine screw with the design power of 2678.35 Watt. Performance test of the turbine was carried out in Nagrak village of Ciherang irrigation canals on Cangkuang Banjaran sub district. With variable discharge, measuring the speed of rotation of the shaft generator, the voltage and current that is produced as well as the efficiency of the turbine. From the results of testing gained $17.82 \%$ efficiency, power turbine 531.84 Watts at discharge 0,277 $\mathrm{m}^{3} / \mathrm{s}$.
\end{abstract}

Keywords: Turbine, Head, Microhydro, Optimazed

\begin{abstract}
ABSTRAK
Turbin air tipe ulir adalah salah satu tipe turbin air yang berpotensi untuk pembangkit listrik skala kecil yang ramah lingkungan, dimana turbin air tipe ulir sangat cocok untuk sungai-sungai di wilayah Indonesia karena pengoperasian turbin ini hanya memerlukan head turbin yang rendah. Melihat potensi air aliran sungai irigasi dengan debit 0,3302 m3/s yang berada di Desa Banjaran memungkinkan pemasangan turbin tipe ulir. Pada proses perancangan turbin air tipe ulir dilakukan optimasi turbin screw dengan menentukan nilai perbandingan $d / D$, lalu melakukan perhitungan mekanikal untuk menentukan dimensi dari sudu turbin, poros turbin, sistem transmisi (roda gigi, puli dan belt) juga daya yang mampu dihasilkan turbin, dengan head 1,05 meter. Hasil dari penelitian ini berupa spesifikasi teknis turbin ulir dengan daya hasil rancangan sebesar 2678,35 Watt dan gambar 2 dimensi serta 3 dimensi turbin ulir hasil rancangan. Hasil perancangan kemudian direalisasikan. Untuk mengetahui kinerja turbin dilakukan pengujian yang dilaksanakan di saluran Irigasi Ciherang Desa Nagrak Kecamatan Cangkuang Banjaran. Dengan variabel ukur yaitu debit, kecepatan putaran poros generator, voltase dan arus yang dihasilkan serta efisiensi turbin. Dari hasil pengujian didapat efisiensi $17.82 \%$, Daya turbin 531.84 Watt pada debit 0,277 $\mathrm{m}^{3} / \mathrm{s}$.
\end{abstract}

Kata kunci: Turbin, Head, Mikrohidro, Optimasi 


\section{PENDAHULUAN}

Kebutuhan akan energi listrik saat ini dirasakan sangatlah penting, baik untuk kebutuhan rumahan, maupun untuk kebutuhan industri yang semakin hari semakin berkembang, sementara unit-unit pembangkit listrik yang ada hampir tidak mengalami peningkatan yang signifikan. Indonesia mempunyai potensi energi terbarukan yang cukup banyak untuk dimanfaatkan salah satunya energi air. Potensi ini belum bisa dimanfaatkan secara optimal karena keterbatasan teknologi turbin dalam memanfaatkan energinya. Untuk head dan debit yang sedang hingga tinggi saat ini masih mengandalkan turbin Pelton, Francis, Kaplan, dan Crossflow. Sedangkan untuk head yang rendah masih sulit untuk dikembangkan, padahal di Indonesia mempunyai potensi yang sangat besar. Perancangan ini didasari atas keterbatasan penyediaan energi listrik di daerah terpencil, padahal sekitar daerah tersebut terdapat sumber energi air yang cukup walaupun mempunyai head yang rendah. Sehingga potensi untuk pembangkit listrik dengan memanfaatkan energi air dengan head rendah perlu dikembangkan. Untuk dapat mengkonversi energi air tersebut diperlukan turbin khusus salah satunya turbin air tipe screw. Prinsip kerja turbin screw ini didasari atas sistem pompa screw yang berfungsi mengangkat air dari sungai menuju permukaan. Turbin screw pada dasarnya merupakan kebalikan dari pompa ulir. Air yang mempunyai head tertentu walaupun dengan debit yang rendah mampu memutar turbin screw yang akan dihubungkan dengan generator untuk menghasilkan listrik. Paper ini membahas perancangan, realisasi dan pengujian turbin screw sebagai pembangkit tenaga listrik.

\section{PROSES PERANCANGAN}

\subsection{Sistem Konversi Energi Air}

Turbin air merupakan alat konversi energi air menjadi energi mekanik, lalu energi mekanik diubah menjadi energi listrik oleh generator. Besarnya energi yang digunakan untuk mengkonversikan energi air menjadi energi listrik, tergantung dari besarnya debit air (Q) yang menumbuk sudu turbin, luas penampang sudu yang terkena air (A) untuk menghasilkan daya (P) [1].

$P=\rho g Q H$

Dimana :

$Q=$ Debit aliran $\left(\mathrm{m}^{3} / \mathrm{s}\right)$

$\rho=$ massa jenis air $\left(\mathrm{kg} / \mathrm{m}^{3}\right)$

$\mathrm{H}=\operatorname{Head}(\mathrm{m})$

$\mathrm{g}=$ Percepatan gravitasi $\left(\mathrm{m} / \mathrm{s}^{2}\right)$

$\mathrm{P}$ = Daya $(\mathrm{W})$

\subsection{Jenis-jenis Turbin Screw}

Blade merupakan bagian penting dalam suatu sistem konversi energi air sebagai komponen yang berinteraksi langsung dengan air. Turbin air tipe screw dibagi dalam dua jenis yaitu tipe steel strough dan tipe closed compact instalation, seperti yang ditunjukkan pada Gambar 1. Turbin screw tipe steel trough adalah tipe turbin yang pada bagian sudu atau bladenya terbuka, sehingga air yang mengalir ke sudu turbin hanya selebar bucket. Sedangkan untuk trubin screw tipe closed compact installation merupakan jenis turbin yang memiliki instalasi keseluruhannya tertutup. Pada turbin tipe ini memungkinkan air yang mengalir menuju sudu turbin hampir bisa memenuhi bagian yang menutupi instalasi turbin. 


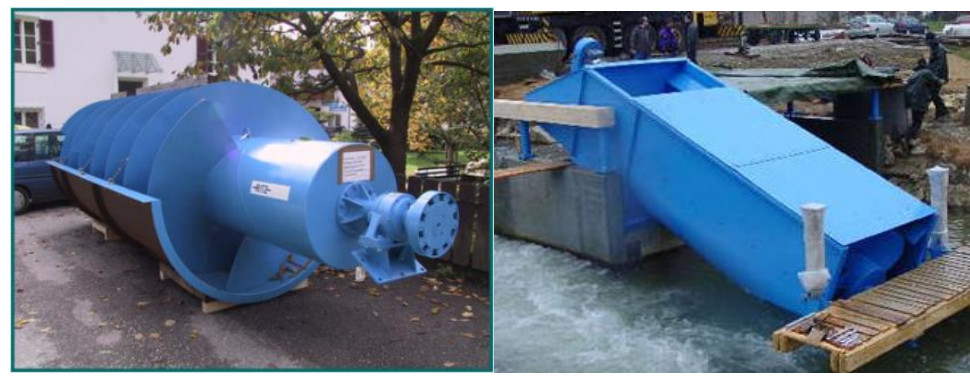

(a)

(b)

Gambar 1. Turbin Screw (a) Tipe Steel Strough dan (b) Tipe Closed Compact Installation [2]

\subsection{Survey Potensi Sungai}

Untuk mendapatkan data-data pendukung dilakukan survey ke lokasi di saluran irigasi sungai Ciherang Banjaran. Data-data yang dibutuhkan diantaranya head sungai, kecepatan aliran sungai dan lebar sungai. Gambar 2 dibawah ini menunjukkan proses pengukuran sungai yang ada di lokasi.
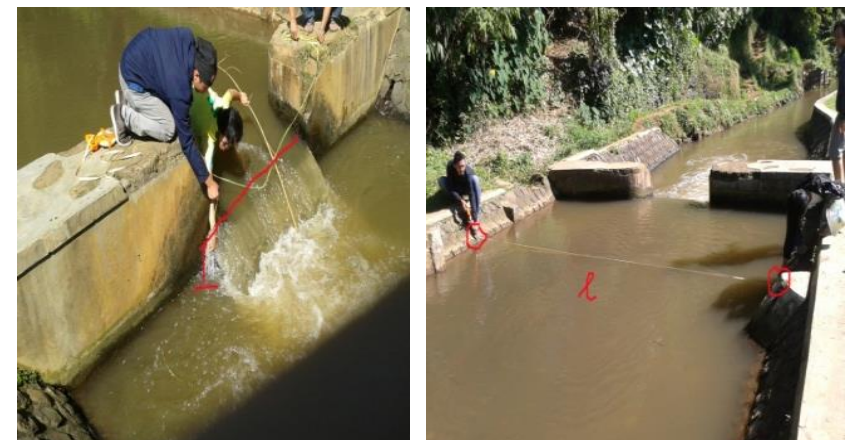

Gambar 2. Proses Pengukuran Lapangan

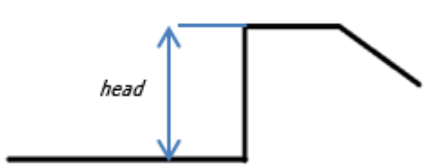

(a)

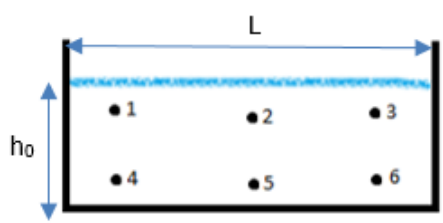

(b)

Gambar 3. Skema Pengukuran (a) Head dan (b) Kecepatan Aliran

Pada Gambar 3 menunjukkan skema pengukuran head sungai dan pada Gambar 5 menunjukkan skema pengukuran aliran sungai, angka 1 sampai 6 menunjukkan titik-titik pengukuran kecepatan aliran kemudian dirata-ratakan. Pengukuran aliran dengan menggunakan currentmeter dan $h_{0}$ menunjukkan kedalaman sungai. 
Hasil dari pengukuran sungai daerah irigasi Ciherang Bandung, adalah sebagai berikut :

1. Head : $1,05 \mathrm{~m}$

2. $\overline{\mathrm{V}}($ Kecepatan aliran $)=0,52 \frac{\mathrm{m}}{\mathrm{s}}$

3. $h_{0}$ ( Kedalaman sungai $)=25,4 \mathrm{~cm}=0,254 \mathrm{~m}$

4. $1=250 \mathrm{~cm}=2,5 \mathrm{~m}$

Dari persamaan debit $\mathrm{Q}=\mathrm{V} \times \mathrm{A}$ dan $\mathrm{A}=\mathrm{h}_{0} \times 1$ didapat debit sebesar $0,3302\left(\mathrm{~m}^{3} / \mathrm{s}\right)$. Dari data sungai daerah irigasi Ciherang didapatkan potensi daya turbin yang dihasilkan, dengan menggunakan persamaan (1) diperoleh :

$P=\rho g Q H$

$P=1000 \frac{\mathrm{kg}}{\mathrm{m}^{3}} \times 9,81 \frac{\mathrm{m}}{\mathrm{s}^{2}} \times 0,3302 \frac{\mathrm{m}^{3}}{\mathrm{~s}} \times 1,05 \mathrm{~m}=3401,22 \mathrm{watt}=3,40 \mathrm{~kW}$

Dimana nilai $\rho$ adalah massa jenis air sebesar $1000 \frac{\mathrm{kg}}{\mathrm{m}^{3}}$

\subsection{Optimasi Turbin Air Type Screw}

Pembahasan yang akan diuraikan adalah mengenai optimasi dari turbin air tipe screw dengan efisiensi yang optimum dengan mempertimbangkan dimensi turbin dan bahan-bahan yang banyak tersedia di pasaran. Untuk menentukan dimensi dari turbin air tipe screw dilakukan optimasi untuk menentukan efisiensi tertinggi dari turbin untuk berbagai sudut ulir, sudut turbin, dan perbandingan diameter. Sehubungan dengan pertimbangan ketersediaan bahan yang ada di pasaran dan kemudahan untuk pembuatan maka dalam optimasi turbin air tipe screw dipilih nilai $\frac{d}{D}=0,3$. Data hasil optimasi turbin screw ditunjukkan pada Tabel 3.

\subsection{Perhitungan Dimensi Turbin Screw}

Menurut persamaan Archimedes screw, dengan debit aliran Q ( $\left.\mathrm{m}^{3} / \mathrm{s}\right)$ diperoleh dari persamaan[2] :

$\mathrm{Q}=\mathrm{kn} \mathrm{D}$

Dimana :

$\mathrm{k}=$ Konstanta ulir

$\mathrm{n}=$ Putaran turbin screw (rpm)

$\mathrm{D}=$ Diameter turbin $(\mathrm{m})$

Untuk nilai konstanta ulir didapat dari tabel nilai konstanta ulir.

Tabel 1. Nilai Konstanta Ulir [2]

\begin{tabular}{cccccccc}
\hline \multirow{2}{*}{$\mathrm{d} / \mathrm{D}$} & \multicolumn{2}{c}{$22^{\circ}$} & \multicolumn{3}{c}{$26^{\circ}$} & \multicolumn{2}{c}{$30^{\circ}$} \\
\cline { 2 - 8 } & $1.0 \mathrm{D}$ & $1.2 \mathrm{D}$ & $0.8 \mathrm{D}$ & $1.0 \mathrm{D}$ & $1.2 \mathrm{D}$ & $0.8 \mathrm{D}$ & $1.0 \mathrm{D}$ \\
\hline 0.3 & 0.331 & 0.335 & 0.274 & 0.287 & 0.286 & 0.246 & 0.245 \\
\hline 0.4 & 0.35 & 0.378 & 0.285 & 0.317 & 0.323 & 0.262 & 0.271 \\
\hline 0.5 & 0.345 & 0.38 & 0.281 & 0.317 & 0.343 & 0.319 & 0.287 \\
\hline 0.6 & 0.315 & 0.351 & - & 0.3 & 0.327 & - & 0.273 \\
\hline
\end{tabular}

Keterangan :

$\mathrm{d} / \mathrm{D}=$ Perbandingan diameter poros turbin terhadap diameter sudu turbin $22^{\circ}, 26^{\circ}, 30^{\circ}=$ sudut ulir $(\alpha)$

Jika sudut turbin $\leq 30^{\circ}$, maka $S=1,2$. D

Jika sudut turbin $=30^{\circ}$, maka $S=1,0 . \mathrm{D}$

Jika sudut turbin $\geq 30^{\circ}$, maka $S=0,8$. D

$\mathrm{S}=$ pitch turbin $(\mathrm{m})$ 
Untuk putaran turbin screw dipilih dari tabel putaran operasi untuk turbin screw, dan dipilih untuk kategori fast yaitu $30 \mathrm{rpm}$.

Tabel 2. Putaran Operasi Turbin Screw [2]

\begin{tabular}{lc}
\hline Speed & Turbine revolution per minute $(\mathrm{rpm})$ \\
\hline Slow & $20-23$ \\
\hline Medium & $25-26$ \\
\hline Fast & $29-31$ \\
\hline
\end{tabular}

Persamaan yang digunakan untuk dimensi turbin screw sebagai berikut [2] :

1. Diameter turbin : D (m)

$$
\begin{aligned}
& D^{3}=\frac{Q}{k n} . \\
& D=\sqrt[3]{\frac{Q}{k n}}
\end{aligned}
$$

Dimana $\quad: \quad \mathrm{k}=$ Nilai konstanta ulir yang diperoleh dari Tabel 1.

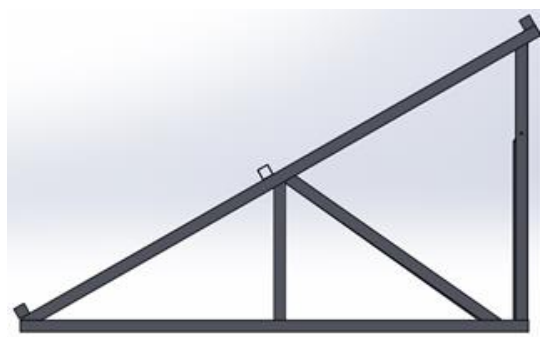

Gambar 4. Sudut Turbin

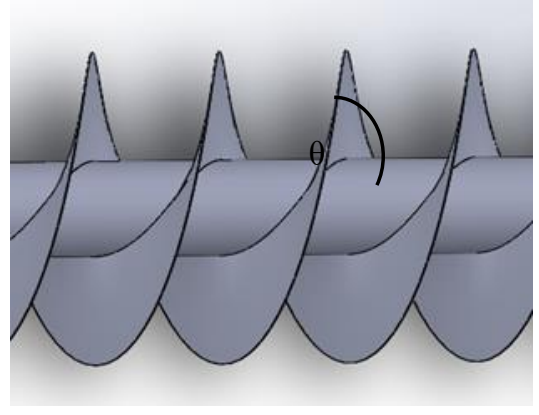

Gambar 5. Sudut Ulir, Diameter Poros Turbin dan Diameter Turbin

2. Diameter poros turbin : $\mathrm{d}(\mathrm{m})$

Untuk perbandingan diameter por ss turbin terh ^dap diameter sudu turbin telah ditentukan [2] :

$\frac{d}{D}=0,3$

3. Panjang turbin : $\mathrm{L}(\mathrm{m})$

$\sin \theta=\frac{\mathrm{H}}{\mathrm{L}}$

Dimana

$$
\begin{aligned}
& \theta=\text { Sudut turbin }\left({ }^{\circ}\right) \\
& \mathrm{H}=\operatorname{Head}(\mathrm{m})
\end{aligned}
$$

4. Pitch turbin : $\mathrm{S}(\mathrm{m})$

Untuk menentukan nilai pitch turbin, terlebih dahulu harus menentukan nilai sudut turbin $(\theta)$ [2]: 
Jika sudut turbin $\leq 30^{\circ}$, maka $\mathrm{S}=1,2 \mathrm{D}$

Jika sudut turbin $=30^{\circ}$, maka $\mathrm{S}=1,0 \mathrm{D}$

Jika sudut turbin $\geq 30^{\circ}$, maka $S=0,8 \mathrm{D}$

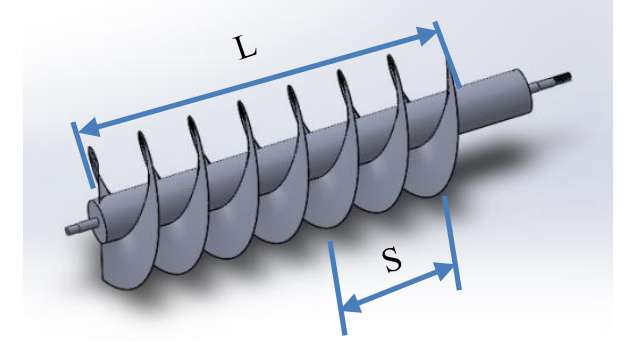

Gambar 6. Panjang Turbin dan Pitch Turbin

5. Jumlah ulir : Z

$\mathrm{Z}=\frac{\mathrm{L}}{\mathrm{S}}$

6. Efisiensi turbin $: \eta$

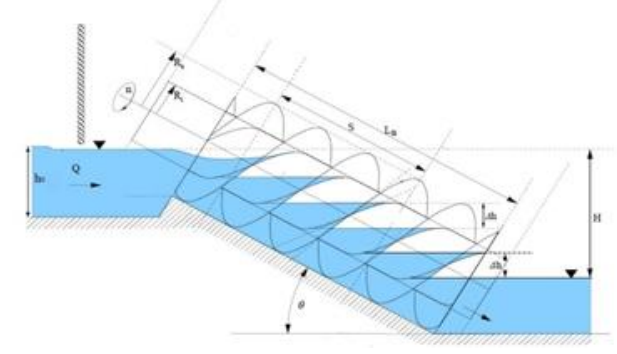

Gambar 7. Parameter Turbin Screw

$$
\begin{aligned}
\eta=\left(\frac{2 \times a+1}{2 \times a+2}\right) x & \left(1-\frac{0,01125 \times D^{2}}{Q}\right) \\
\text { Dimana }: a & =\frac{\mathrm{h}_{0}}{\Delta \mathrm{h}} \\
\Delta \mathrm{h} & =\mathrm{x} \sin \theta \\
\mathrm{x} & =\frac{1}{\mathrm{~N}} \mathrm{~S} \\
\mathrm{~N} & =\mathrm{Jumlah} \text { blade }
\end{aligned}
$$

7. Daya turbin yang dihasilkan $\mathrm{P}(\mathrm{W})[3,4]$ :

$\mathrm{P}=\rho \mathrm{g} \mathrm{QH} \eta$

Berikut data yang didapat dari hasil optimasi. 
Tabel 3. Optimasi Turbin Screw

\begin{tabular}{|c|c|c|c|c|}
\hline \multirow{2}{*}{ No } & \multirow{2}{*}{$\mathrm{d} / \mathrm{D}$} & \multirow{2}{*}{ Sudut } & \multicolumn{2}{|c|}{ Efisiensi } \\
\hline & & & $\mathrm{N}=1$ & $\mathrm{~N}=2$ \\
\hline 1 & \multirow{9}{*}{0.3} & Sudut Ulir $22^{\circ}$ Sudut Turbin $25^{\circ}$ & 0,7009 & 0,7852 \\
\hline 2 & & Sudut Ulir $22^{\circ}$ Sudut Turbin $30^{\circ}$ & 0,7021 & 0,7865 \\
\hline 3 & & Sudut Ulir $26^{\circ}$ Sudut Turbin $25^{\circ}$ & 0,6934 & 0,7777 \\
\hline 4 & & Sudut Ulir $26^{\circ}$ Sudut Turbin $30^{\circ}$ & 0,6953 & 0,7795 \\
\hline 5 & & Sudut Ulir $26^{\circ}$ Sudut Turbin $35^{\circ}$ & 0,7033 & 0,7875 \\
\hline 6 & & Sudut Ulir $26^{\circ}$ Sudut Turbin $40^{\circ}$ & 0,6897 & 0,7739 \\
\hline 7 & & Sudut Ulir $30^{\circ}$ Sudut Turbin $30^{\circ}$ & 0,6876 & 0,7717 \\
\hline 8 & & Sudut Ulir $30^{\circ}$ Sudut Turbin $35^{\circ}$ & 0,6981 & 0,7822 \\
\hline 9 & & Sudut Ulir $30^{\circ}$ Sudut Turbin $40^{\circ}$ & 0,6845 & 0,7686 \\
\hline 10 & \multirow{9}{*}{0.4} & Sudut Ulir $22^{\circ}$ Sudut Turbin $25^{\circ}$ & 0,7067 & 0,7905 \\
\hline 11 & & Sudut Ulir $22^{\circ}$ Sudut Turbin $30^{\circ}$ & 0,7047 & 0,7901 \\
\hline 12 & & Sudut Ulir $26^{\circ}$ Sudut Turbin $25^{\circ}$ & 0,6992 & 0,7836 \\
\hline 13 & & Sudut Ulir $26^{\circ}$ Sudut Turbin $30^{\circ}$ & 0,7000 & 0,7844 \\
\hline 14 & & Sudut Ulir $26^{\circ}$ Sudut Turbin $35^{\circ}$ & 0,7052 & 0,7894 \\
\hline 15 & & Sudut Ulir $26^{\circ}$ Sudut Turbin $40^{\circ}$ & 0,6916 & 0,7759 \\
\hline 16 & & Sudut Ulir $30^{\circ}$ Sudut Turbin $30^{\circ}$ & 0,6925 & 0,7767 \\
\hline 17 & & Sudut Ulir $30^{\circ}$ Sudut Turbin $35^{\circ}$ & 0,7011 & 0,7853 \\
\hline 18 & & Sudut Ulir $30^{\circ}$ Sudut Turbin $40^{\circ}$ & 0,6876 & 0,7717 \\
\hline 19 & \multirow{9}{*}{0.5} & Sudut Ulir $22^{\circ}$ Sudut Turbin $25^{\circ}$ & 0,7069 & 0,7906 \\
\hline 20 & & Sudut Ulir $22^{\circ}$ Sudut Turbin $30^{\circ}$ & 0,7041 & 0,7884 \\
\hline 21 & & Sudut Ulir $26^{\circ}$ Sudut Turbin $25^{\circ}$ & 0,7021 & 0,7865 \\
\hline 22 & & Sudut Ulir $26^{\circ}$ Sudut Turbin $30^{\circ}$ & 0,7000 & 0,7844 \\
\hline 23 & & Sudut Ulir $26^{\circ}$ Sudut Turbin $35^{\circ}$ & 0,7046 & 0,7887 \\
\hline 24 & & Sudut Ulir $26^{\circ}$ Sudut Turbin $40^{\circ}$ & 0,6906 & 0,7752 \\
\hline 25 & & Sudut Ulir $30^{\circ}$ Sudut Turbin $30^{\circ}$ & 0,6953 & 0,7796 \\
\hline 26 & & Sudut Ulir $30^{\circ}$ Sudut Turbin $35^{\circ}$ & 0,7481 & 0,7948 \\
\hline 27 & & Sudut Ulir $30^{\circ}$ Sudut Turbin $40^{\circ}$ & 0,7107 & 0,7814 \\
\hline 28 & \multirow{5}{*}{0.6} & Sudut Ulir $22^{\circ}$ Sudut Turbin $25^{\circ}$ & 0,7032 & 0,7867 \\
\hline 29 & & Sudut Ulir $22^{\circ}$ Sudut Turbin $30^{\circ}$ & 0,6998 & 0,7842 \\
\hline 30 & & Sudut Ulir $26^{\circ}$ Sudut Turbin $25^{\circ}$ & 0,6998 & 0,7842 \\
\hline 31 & & Sudut Ulir $26^{\circ}$ Sudut Turbin $30^{\circ}$ & 0,6974 & 0,7817 \\
\hline 32 & & Sudut Ulir $30^{\circ}$ Sudut Turbin $30^{\circ}$ & 0,6930 & 0,7772 \\
\hline
\end{tabular}

Hasil dari optimasi turbin air tipe screw diperoleh :

Tabel 4. Hasil Optimasi Turbin Screw

\begin{tabular}{cl}
\hline Perbandingan Diameter $(\mathrm{d} / \mathrm{D})$ & 0,3 \\
\hline Sudut Ulir $(\alpha)$ & $26^{\circ}$ \\
\hline Sudut Turbin $(\theta)$ & $35^{\circ}$ \\
\hline
\end{tabular}

\subsection{Hasil Perancangan}

Hasil dari perhitungan diperoleh hasil rancangan turbin air tipe screw untuk pembangkit listrik skala mikrohidro yang dapat dilihat pada Tabel 5 dan gambar 2D serta 3D hasil dari rancangan. 
Tabel 5. Data Sesifikasi Teknik Rancangan Turbin Air Tipe Screw

\begin{tabular}{|c|c|c|}
\hline \multicolumn{3}{|c|}{ Data Hasil Rancangan Turbin Air Tipe Screw } \\
\hline No. & Data & Nilai \\
\hline 1. & Sudut Ulir & $26^{\circ}$ \\
\hline 2. & Sudut Turbin & $35^{\circ}$ \\
\hline 3. & Kecepatan Putaran Turbin & $30 \mathrm{rpm}$ \\
\hline 4. & Diameter Turbin & $726,6 \mathrm{~mm}$ \\
\hline 5. & Diameter Poros Turbin & $217,9 \mathrm{~mm}$ \\
\hline 6. & Panjang Turbin & $2,043 \mathrm{~m}$ \\
\hline 7. & Pitch Turbin & $581,2 \mathrm{~mm}$ \\
\hline 8. & Jumlah Blade dan Ulir & 2 buah dan 7 buah \\
\hline 9. & Efisiensi Turbin & $78,75 \%$ \\
\hline 10. & Potensi Daya Sungai & 3401,22 watt \\
\hline 11. & Daya Turbin Hasil Rancangan & 2678,35 watt \\
\hline 12. & Kapasitas Generator AC & 3000 watt dengan putaran $1500 \mathrm{rpm}$ \\
\hline 13. & Diameter Puli & $76,2 \mathrm{~mm}, 228,6 \mathrm{~mm}$ dan $304,8 \mathrm{~mm}$ \\
\hline 14. & Diameter Roda Gigi Penggerak & $315 \mathrm{~mm}$ \\
\hline 15. & Diameter Roda Gigi yang Digerakkan & $75 \mathrm{~mm}$ \\
\hline 16. & Tebal Roda Gigi & $30 \mathrm{~mm}$ \\
\hline 17. & Tipe Sabuk & $\mathrm{A}-47$ dan $\mathrm{B}-61$ \\
\hline 18. & Diameter Poros Tingkat 1 ( CD ) & $46 \mathrm{~mm}$ \\
\hline 19. & Diameter Poros Tingkat 2 ( EF ) & $34 \mathrm{~mm}$ \\
\hline 20. & Diameter Poros Tingkat $3(\mathrm{GH})$ & $25 \mathrm{~mm}$ \\
\hline 21. & Perbandingan Inkrisi & $4,2: 4: 3$ \\
\hline 21. & Kontruksi Frame Turbin & Baja Siku 50 x $50 \mathrm{~mm}$ dan 40 x $40 \mathrm{~mm}$ \\
\hline
\end{tabular}

Gambar 3D dan 2D turbin air tipe screw hasil rancangan ditunjukkan pada gambar 8 sebagai berikut:
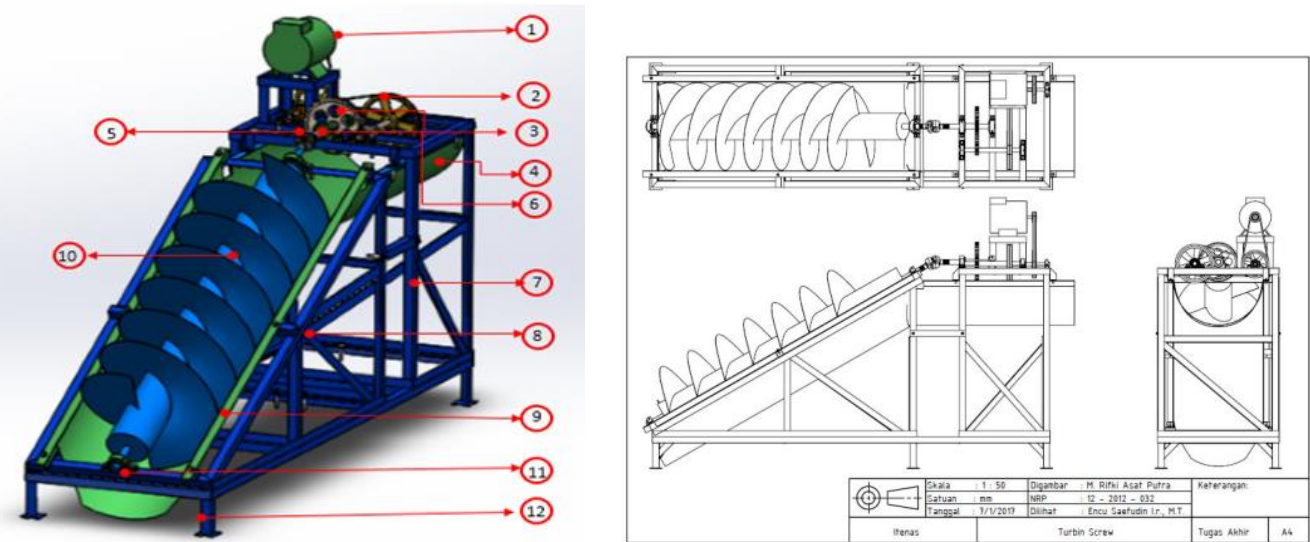

Keterangan :
1. Generator
2. Puli dan sabuk
3. Roda Gigi
4. Bucket Transmisi
5. Universal Joint
6. Poros Transmisi
7. Frame Transmisi

8. Frame Sudu

9. Bucket Sudu

10. Poros screw

11. Pillow Block

12. Frame dudukan Turbin

Gambar 8. Gambar 3D dan 2D sistem turbin screw 


\section{REALISASI}

Head pada data awal perancangan sebesar 1,05 meter didapatkan panjang turbin 1,831 meter dengan jumlah ulir 3,15. Dengan nilai jumlah ulir 3,15 maka dilakukan pembulatan nilai keatas menjadi 3,5 ulir untuk setiap blade-nya, sehingga panjang turbin menjadi 2,043 meter [5]. Dengan dampak energi air yang dikonversikan oleh turbin menjadi lebih besar. Transmisi tingkat satu dipilih jenis roda gigi, karena pada poros tingkat satu dengan putaran yang kecil, maka nilai $\mathrm{T}$ (torsi) akan besar, dengan mempertimbangkan faktor estetika dimensi karena putaran turbin yang rendah dan ingin mendapatkan dimensi turbin yang se-compact mungkin, maka tidak digunakan sistem transmisi puli dan sabuk. Jika tetap menggunakan sistem puli dan sabuk, dimensinya akan sangat besar dan menggunakan jenis puli tipe $\mathrm{C}$ dengan lebih dari dua jalur.Adapun spesifikasi material adalah sebagai berikut :

Tabel 6. Spesifikasi Material

\begin{tabular}{ll}
\hline \multicolumn{1}{c}{ Data } & \multicolumn{1}{c}{ Spesifikasi Material } \\
\hline Generator & Ac, 3000 Watt, putaran 1500 rpm \\
\hline Sudu Turbin & Baja Pelat \\
\hline Poros Turbin & S45C \\
\hline Roda Gigi & S45C \\
\hline Puli & Besi Cor \\
\hline Poros Transmisi & S45C \\
\hline Universal Joint & Colt Diesel PS 100 \\
\hline Bucket & Baja Pelat \\
\hline Pillow Block & UCP 206, UCP 204, UCP 208 \\
\hline Frame & Baja Siku \\
\hline Sabuk & Rubber \\
\hline
\end{tabular}

\section{PEMASANGAN DAN PENGUJIAN}

Pemasangan dan pengujian turbin air tipe screw dilaksanakan di saluran Irigasi Ciherang, Banjaran. Di koordinat ( $\left.7^{\circ} 03^{\prime} 50.4^{\prime \prime S} 107^{\circ} 33^{\prime} 20.9^{\prime \prime E}\right)$. Proses pemasangan dan pengujian dapat dilihat pada Gambar 9.
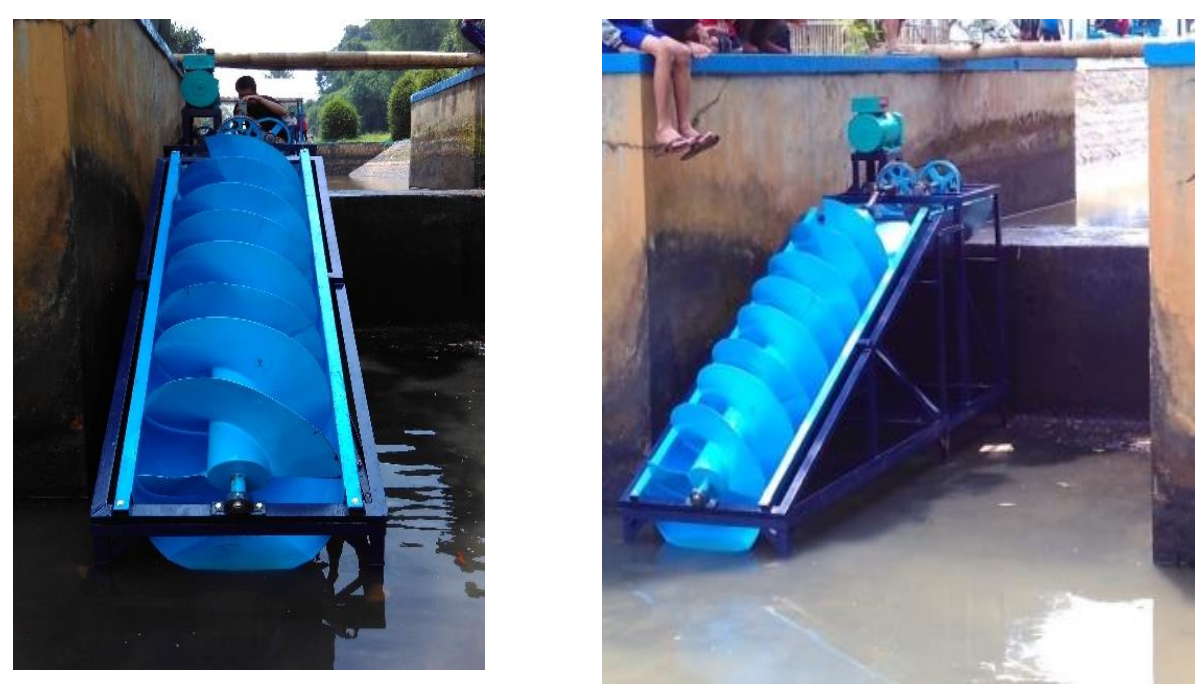

Gambar 9. Proses Pemasangan dan Pengujian Turbin di Lokasi 
Pengujian turbin air ini bertujuan untuk mengetahui prestasi turbin ulir dengan variasi debit dan beban. Prestasi tersebut meliputi daya yang tersedia, daya generator turbin dan efisiensi turbin. Skema pengujian bisa dlihat pada Gambar 10.

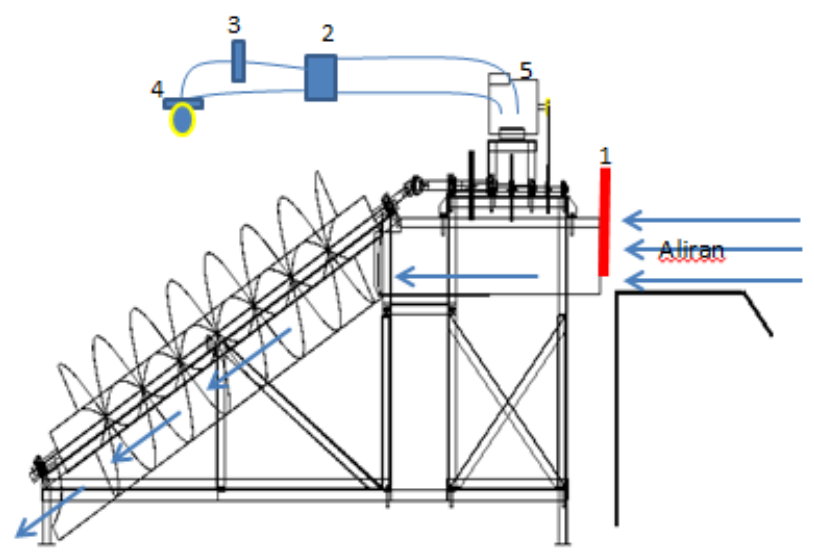

Gambar 10. Skema Pengujian

Keterangan :

1. Papan ukur

2. Voltmeter

3. Amperemeter

4. Lampu

5. Generator

Pengaturan variasi debit yang masuk ke turbin dengan menggunakan papan ukur pada bukaan $0,15 m, 0,20 m, 0,25 \mathrm{~m}$. Langkah pertama pada bukaan 0,15 $\mathrm{m}$. Langkah kedua mengukur kecepatan aliran air yang masuk ke turbin dengan menggunakan currentmeter, langkah ketiga mengukur kecepatan turbin dan generator menggunakan tachometer, langkah keempat mengukur tegangan dan kuat arus yang keluar dari generator kemudian dicatat, ulangi sampai bukaan papan ukur sampai $0,25 \mathrm{~m}$. Tahap pengambilan data bisa dilihat pada Gambar 11 .

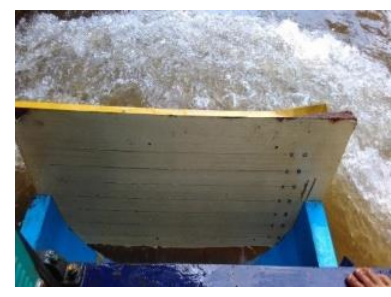

(a)

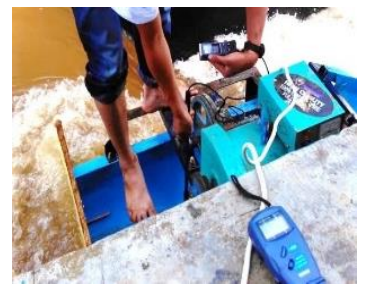

(b)

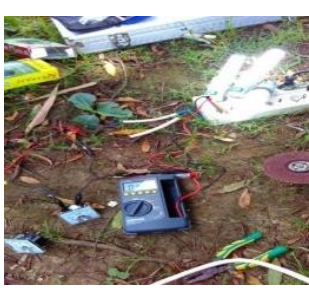

(c)

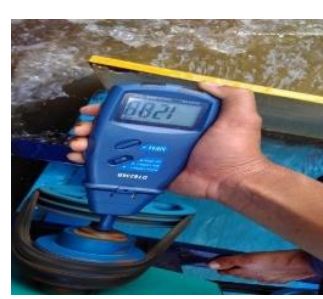

(d)

Gambar 11. Proses Pengambilan Data Pengujian, (a) Bukaan Papan Ukur (b)Pengukuran Kecepatan Aliran, (c) Pengukuran Putaran

(d) Pengukuran Arus Dan Tegangan, 


\section{HASIL PENGUJIAN DAN ANALISA}

Berdasarkan pengujian dilakukan untuk menganalisa pengaruh debit terhadap daya. Hasil pengujian dapat dilihat pada Gambar 12. Dari Gambar 12 tersebut dilihat bahwa semakin tinggi debit daya turbin naik. Karena pengujian dibatasi hanya sampai debit $0,277 \mathrm{~m}^{3} / \mathrm{s}$ maka, daya yang dihasilkan hanya mampu 531.84 Watt. Berdasarkan data perencanaan turbin akan menghasilkan daya $3401 \mathrm{Watt}$ pada debit $0,3302 \mathrm{~m}^{3} / \mathrm{s}$. Sehingga turbin yang diuji ini mempunyai daya lebih rendah dibandingkan data perancangan. Hal ini disebabkan ada perubahan sudut sudu dibandingkan dengan rancangan. Selama turbin beroperasi banyak air tumpah keluar sudu, sehingga mempengaruhi daya maksimum turbin.

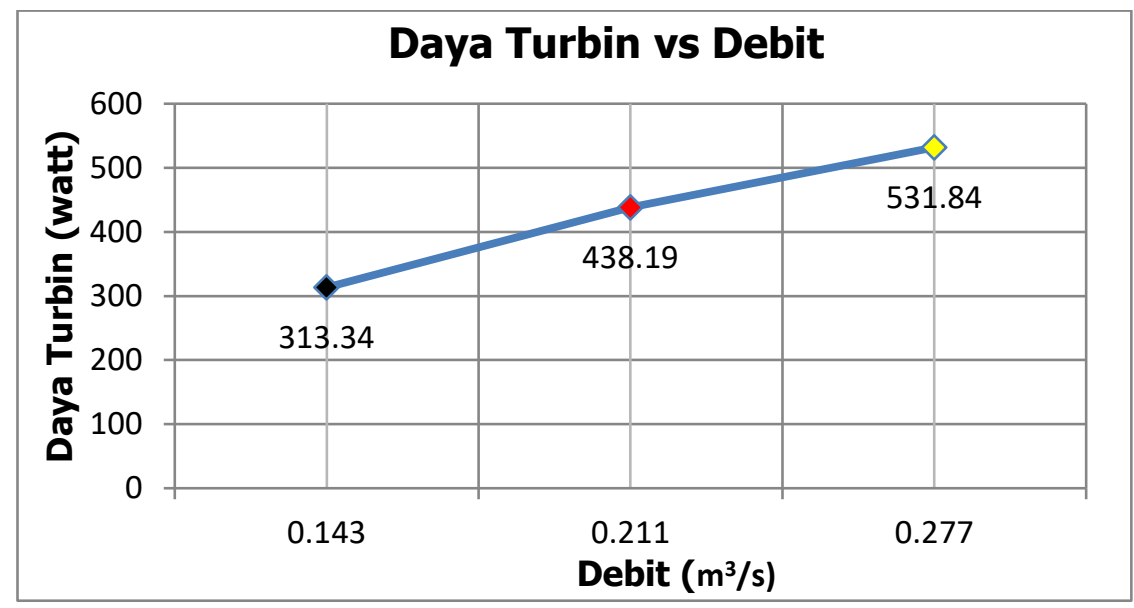

Gambar 12. Grafik Daya Turbin Vs Debit

Gambar 13 menjelaskan pengaruh efisiensi terhadap debit. Dari gambar tersebut terlihat bahwa semakin tinggi debit, efisiensinya meningkat, namun efisiensi turbin pada debit maksimum $0,277 \mathrm{~m}^{3} / \mathrm{s}$ hanya mencapai $17.82 \%$. Berdasarkan perencanaan efisiensi turbin pada debit maksimum $0,3302 \mathrm{~m} / \mathrm{s}$ adalah $78,75 \%$, sehingga bila dibandingkan dengan perencanaan awal, efisiensi turbin yang diuji lebih rendah. Hal ini disebabkan selain faktor kebocoran dan perubahan sudut yang disebut dalam pembahasan sebelumnya, juga disebabkan rugi-rugi transmisi sabuk cukup besar.

\section{Efisiensi vs Debit}

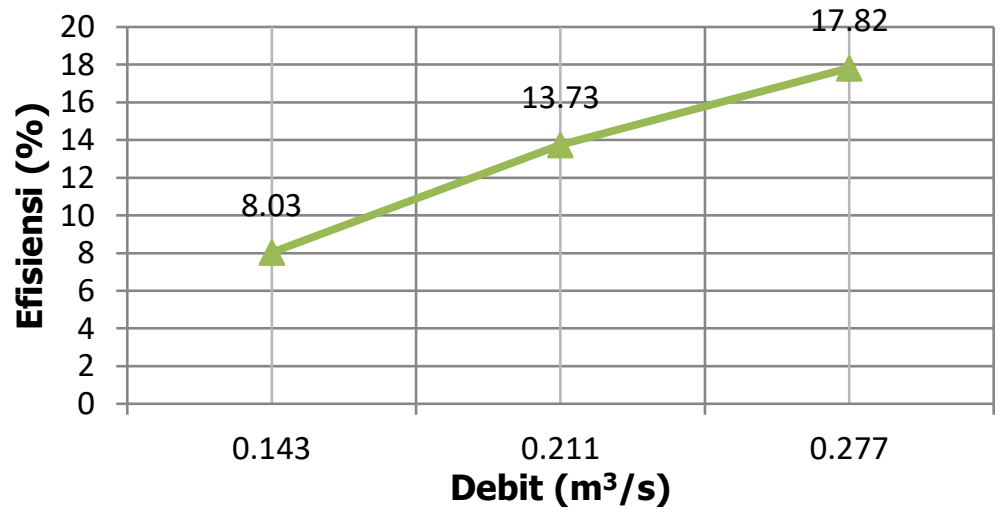

Gambar 13. Grafik Efisiensi Vs Debit 


\section{KESIMPULAN}

Dan hasil pengujian menghasilkan daya maksimum dan efisiensi maksimum generator turbin adalah 521.84 Watt dan $17,82 \%$ pada debit $0,277 \mathrm{~m}^{3} / \mathrm{s}$.

\section{DAFTAR PUSTAKA}

[1] Dietzel, Fritz. 1990. “Turbin, Pompa dan Kompresor”, Jakarta: Penerbit Erlangga.

[2] Rorres (1987). Jurnal "The Turn Of The Screw Optimal Design Of An Archimedes Screw”.

[3] Arismunandar, Wiranto. 2004, "Penggerak Mula Turbin", Bandung: Penerbit ITB

[4] Soedrajat S, Ir. 1983, "Mekanika Fluida dan Hidrolika", Bandung: Penerbit NOVA

[5] Havendri, A. dan Lius, H., 2009, "Perancangan dan Realisasi Model Prototipe Turbin Air Type Screw (Archimedean Turbine) untuk Pembangkit Listrik Tenaga Mikrohidro dengan Head Rendah di Indonesia”, Jurnal Teknik, No.31 Vol.2 Thn. XVI April 2009, ISSN: 0854-8471. 